\title{
Sistem Ekonomi Gotong Royong: Implementasi Konsep Ekonomi Relasional yang Berakar pada Komunitas
}

\author{
Victor Christianto ${ }^{1}$, Robby I. Chandra², Satyo Laksono ${ }^{3}$ \\ ${ }^{1}$ Sekolah Tinggi Teologi Satyabhakti Jakarta, Indonesia \\ ${ }^{2}$ Sekolah Tinggi Teologi Cipanas, Jawa Barat, Indonesia \\ ${ }^{3}$ Indonesian Institute of Advanced Studies and Appropriate Technologies (IIASART) \\ Correspondence: victorchristianto@gmail.com
}

\begin{abstract}
In the modern economy, human beings become homo economicus a concept where consumers become objects of the economic system as their main role is just as spenders or buyers. As an alternative concept, Ekonomi Gotong Royong offers a system based on relational and communal values where the people play roles both as the buyers and the producers, or managers, and share-holders This writing is an exploration on the possibility to apply such an alternative system by analyzing its principles, needed capitals (economic, moral, and social), main components, and example in microeconomic settings. The result shows that the system can work if the stakeholders meet three prerequisites: continuous education for mindset and skillset development, moral values awareness, and spiritual foundation.
\end{abstract}

Keywords: consumer engagement; empowerment; relational economy; society empowerment

\begin{abstract}
Abstrak: Dalam ilmu ekonomi modern manusia seringkali menjadi homo ekonomikus, saat konsumen menjadi objek dari sistem ekonomi dan mereka berperan sebagai pembelanja saja. Pilihan lain adalah menerapkan sistem Ekonomi Gotong Royong yang berlandaskan nilai-nilai relasional dan komunitas sehingga orang banyak berperan baik sebagai pembelanja atau konsumen, produsen, dan pengelola dana serta pemegang saham. Tulisan ini menelusuri kemungkinan mewujudkan sistem tersebut dengan meneliti prinsip-prinsip dasarnya, modal yang diperlukan baik modal moral atau nilai dan ekonomis, komponen-komponennya, dan bagaimana contoh prosesnya di dalam skala ekonomi mikro. Sejauh ini ditemukan bahwa, sistem tersebut akan berjalan bila tiga syarat terpenuhi yaitu: pendidikan berkelanjutan untuk menyamakan mindset dan skillset para pemeran, serta kesadaran nilai-nilai moral, dan landasan spiritualitas yang mendalam.
\end{abstract}

Kata kunci: ekonomi relasional; keterlibatan konsumen; pemberdayaan; pemberdayaan masyarakat

\section{Pendahuluan}

Dari pandangan ekonomi modern, suatu negara yang memiliki penduduk sekitar 279,2 juta orang ${ }^{1}$ dan pertumbuhan populasi yang tetap akan dipandang sebagai bangsa yang memiliki modal ${ }^{2}$ dan pasar potensial yang besar. Jumlah penduduk sebesar itu dipandang sebagai kumpulan konsumen yang akan menyerap produk atau layanan yang ditawarkan.

\footnotetext{
${ }^{1}$ Badan Pusat Statistik, "Hasil Sensus Penduduk 2020," Januari, 2021, https://www.bps.go.id/pressrelease/2021/01/21/1854/hasil-sensus-penduduk-2020.html.

2 Hippolyte d'Albis, "Demographic Structure and Capital Accumulation," Journal of Economic Theory 132, no. 1 (January 2007): 411-34, doi:10.1016/j.jet.2005.10.001.
} 
Pandangan serupa itu memang lumrah di dalam Pemikiran ekonomi pasar. Dalam pemikiran tersebut, para pemilik modal akan menggunakan modalnya memproduksi atau menyediakan layanan tertentu sesuai kemampuan mereka membaca kebutuhan konsumen dan kemampuan operasional menyediakannya. Sejauh ini dunia memang hidup dengan Pemikiran di atas. Jadi dalam konsep tersebut, orang banyak atau penduduk dipandang sebagai sasaran proses marketing dan produksi. Siapa yang dapat menata kedua hal tersebut dengan baik akan meraup laba. Pemikiran ini dapat diterima dan digunakan karena dorongan untuk meraih laba secara faktual menjadi suatu pendorong yang kuat terjadinya roda ekonomi selain menjadi sarana untuk mencapai kepuasan kejiwaan diri sebagaimana diajarkan dalam berbagai kajian dalam studi enterpreneurship. ${ }^{3}$

Namun, kelemahan dari pemikiran ini terdapat pada perspektif bahwa orang banyak terutama dipandang dan diperlakukan sebagai konsumen yang merupakan suatu sasaran dari proses yang panjang. Dari sudut filosofis mereka dipandang sebagai sasaran atau objek dalam suatu sistem kemasyarakatan yang ada. Konsep seperti itu diperkuat padangan homo economicus atau manusia (melulu untuk tujuan) ekonomi yang dipergunakan oleh John Stuart Mills di abad 19 ketika ia membahas mengenai manusia, politik, dan ekonomi. "... does not treat the whole of man's nature as modified by the social state, nor of the whole conduct of man in society. It is concerned with him solely as a being who desires to possess wealth, and who is capable of judging the comparative efficacy of means for obtaining that end." ${ }^{4}$

Tulisan ini dapat dilihat merupakan upaya kelanjutan dari artikel yang pernah penulis sampaikan dalam seminar sehari yang diadakan oleh OCRPL, November 2020, dalam hubungannya dengan pendidikan teologi transformatif. ${ }^{5}$ Selain itu, upaya yang dipaparkan di sini dapat juga dilihat sebagai upaya mengembangkan teologi oleh rakyat, khususnya dalam hubungannya dengan penerapan gagasan para founding fathers negara ini, yaitu negara gotong-royong. ${ }^{6}$

Dasar pemikiran ini pertama terletak dari kenyataan bahwa dalam jumlah yang besar terdapat potensi modal yang tidak dihitung sebelumnya. ${ }^{7}$ Kedua, pakar media, Henry Jenkins menyatakan bahwa di dalam era digital kata kunci dari seluruh proses ekonomi, sosial, agama, dan politik adalah "Engagement" atau keterlibatan orang di samping "networking", "konvergensi" (saling terjalin), dan interaksi selain ekspresi dan berbagai informasi. ${ }^{8}$ Misalnya, dari pengamatan umum, ibu-ibu rumah tangga berperan sebagai manajer keuangan dalam kehidupan rumah tangganya. Hal ini terjadi di berbagai tingkat sosial masyarakat. Sepintas

\footnotetext{
${ }^{3}$ Ilyos Makhmudovich Khasanov, "Essence, Mission And Value Of Enterpreneurship Activity," The American Journal of Management and Economics Innovations 03, no. 02 (February 28, 2021): 38-45, doi:10.37547/tajmei/volume03issue02-05.

${ }^{4}$ Mills, John Stuart. "On the Definition of Political Economy, and on the Method of Investigation Proper to It," London and Westminster Review, October 1836. Essays on Some Unsettled Questions of Political Economy, 2nd ed. London: Longmans, Green, Reader \& Dyer, 1874, essay 5, paragraphs 38 and 48.

${ }^{5}$ Robby I. Chandra \& V. Christianto. Paper on Koinomics, presented at OCRPL seminar on Transformative Theological Education, OCRPL's one day webinar, November 2020.

${ }^{6}$ Samuel Amirtham \& John S. Pobee (eds.), Teologi oleh Rakyat. Jakarta: BPK Gunung Mulia, 1993. Lihat juga : Agustinus W. Dewantara. "Alangkah hebatnya negara gotong-royong" (Indonesia dalam kacamata Soekarno). Yogyakarta: Penerbit PT Kanisius, 2017.

${ }^{7}$ Paul H. Thibodeau and Lera Boroditsky, "Metaphors We Think with: The Role of Metaphor in Reasoning," PLOS ONE 6, no. 2 (2011), doi:10.1371/journal.pone.0016782.

8 "The Power of Large Numbers: Population, Politics, and Gender in Nineteenth-Century France on JSTOR," accessed April 16, 2021, https://www.jstor.org/stable/10.7591/j.ctv75d49n.
} 
terbaca, sistem ekonomi pasar kurang mendukung ibu-ibu itu dalam memenuhi segala kebutuhan rumah tangganya, maka ibu-ibu rumah tangga tersebut harus berpikir keras dan bekerja keras dengan berbagai macam cara agar posisi keuangan di dalam rumah tangganya dapat berjalan secara seimbang.

Bila ibu-ibu rumah tangga tersebut dalam mengelola keuangannya di tingkat akar rumput dapat ikut mengelola usaha mereka dalam upaya memenuhi segala kebutuhannya itu, maka kita dapat bertanya: "Mungkinkah ada cara pengelolaan belanja rutin sehari-hari yang biasanya dilakukan oleh ibu-ibu rumah tangga tersebut untuk menjadi juga sebuah investasi jangka panjang bagi masa depan keluarganya?" Pemikiran ini dipaparkan secara ringkas dalam artikel ini, dan untuk menjadi bahan eksplorasi baik untuk menjelaskan konsep dasarnya, faktor penentu, praysarat, dan contoh keberhasilan.

Pentingnya pemikiran tersebut terkait dengan datangnya krisis ekonomi yang tidak disangka dan memiliki kemungkinan akan terus berlangsung sampai beberapa tahun yang akan datang. Kemudian, ketika tatanan ekonomi dunia akan diperbaharui dan ditata ulang oleh mekanisme kehidupan ini maupun oleh konsep rekayasa para globalis yang akan terus mempertahankan konsep ekonomi kapitalis dengan model piramida ekonomi, dan telah terbukti kesenjangan ekonomis terus meningkat. Dengan kata lain, sistem yang ada dan sudah lama sangat menekankan pemisahan antara konsumen dengan produsen selain membedakan pemilik modal dan penerima produk. Sementara konsumen sebagai penerima atau pengguna individual terbiasa terpisah-pisah, terpisah, dan terserak.

\section{Pembahasan}

Pada intinya sistem ekonomi gotong royong yang ditawarkan ini berupa proses menyatukan transaksi simpan-pinjam dan transaksi perdagangan di bawah satu payung. Sehingga diharapkan asas manfaat bersama dalam koperasi (pasal 33 UUD 1945) itu betul betul dapat dimaksimalkan. Prasyarat utama untuk keberhasilan adalah semangat untuk berbagi, khususnya dari pihak investor sebagai inisiator awal. Dalam hal ini suatu lembaga, yayasan atau gereja juga dapat menjadi inisiator. Lalu hambatan yang mungkin ditemui, selain mencari investor yang memiliki dana, hati, juga diperlukan tim pengurus yang termotivasi, jujur dan mau bekerja untuk kebaikan bersama. Selebihnya, masyarakat tentu akan lebih mudah untuk dimotivasi untuk berbagi.

Tiga contoh yang diberikan di bagian akhir itu sekadar ilustrasi bahwa sistem ini sangat fleksibel untuk diterapkan dalam berbagai situasi. Kami melihat konsep ini cukup menarik, paling tidak untuk membantu menguraikan kejumudan situasi koperasi di Indonesia saat ini yg sulit berkembang. Padahal di banyak negara Eropa, model koperasi cukup berpengaruh dalam ekonomi nasional. ${ }^{9}$ Demikian semoga paper ini dapat menjadi bahan diskusi yang baik.

\section{Sistem Ekonomi Gotong Royong}

Konsep yang ditawarkan untuk menjawab pertanyaan di atas dan kemungkinan menjadikan orang banyak sebagai subjek dan peserta sistem ekonomi modern disebut sebagai Sistem Ekonomi Gotong Royong. Pada dasarnya sistem ini menempatkan konsumen dalam posisi terorganisir serta berinteraksi dengan sesama konsumen, sehingga memungkinkan terwujudnya asas manfaat bersama sebagai nilai-nilai dalam koperasi yang tercantum dalam Pasal 33, UUD 1945. Dengan demikian sistem tersebut akan menolong para ibu-ibu di akar rumput sebagai konsumen agar menyadari perannya sebagai pelaku pasar dan sekaligus sebagai pe-

\footnotetext{
${ }^{9}$ Dirk J. Lehnhoff. Cooperatives Europe Key figures 2015. Cooperatives Europe.
} 
milik pasar itu sendiri. Dengan demikian, kesadaran serupa itu akan menjadi fondasi dari suatu sistem ekonomi yang berkedaulatan rakyat, yaitu dari rakyat untuk rakyat dan oleh rakyat. Pertanyaannya, bagaimana melaksanakan hal tersebut?

Secara praktis, hal ini diterapkan dalam dua hal. Pertama adalah dalam transaksi simpan pinjam. Pinjaman dana akan diberlakukan tanpa memberikan bunga dengan besarnya angsuran yang dapat dinegosasikan bersama. Selanjutnya juga akan dibuat sistem penyisihan dari suatu transaksi. Misalnya, dari setiap transaksi jual beli seseorang akan mendapatkan voucher yang pada dasarnya merupakan sebagian dari laba yang dibagikan kepada konsumen dalam proses jual beli. Besarannyapun akan disepakati bersama, bukan sebagai diskon yang ditentukan hanya oleh penjual. Dengan kedua metode tersebut, maka pemilik modal dan mereka yang membutuhkan, produsen dan konsumen, penjual dan pembeli, serta peminjam dan yang meminjamkan dilatih untuk berdialog, mencapai kesepakatan, dan keuntungan bersama berjangka panjang. Selain itu, aspek ekonomis dan fisik diharapkan terlayani bersama aspek kejiwaan yaitu kebersamaan secara komunal yang merupakan kekhasan manajemen dan pola pikir Asia. $^{10}$

\section{Dasar-dasar Ekonomi Gotong-Royong}

Kita sudah mengenal konsep ekonomi kerakyatan itu sejak Dasar Negara Pancasila dan Pembukaan UUD 1945 itu ditetapkan, bahkan sebenarnya kehidupan ekonomi kerakyatan itu sudah menjadi budaya di negara Indonesia ini. Para ekonom dan para pakar ekonomi di Indonesia mulai dari bapak Drs. Mohamad Hatta sampai Profesor Mubyarto (UGM) dan kawan-kawan sudah menyampaikan berbagai model konsep ekonomi kerakyatan itu. Namun konsep-konsep yang bagus itu pada umumnya masih belum dapat direalisasikan secara kongkrit di lapangan. Mungkin hanya model koperasi saja yang sudah sempat diperkenalkan dalam lingkup nasional.

Semua sistem ekonomi baik kapitalis dan kapitalisme ersatz (semu) menggunakan pendekatan modern. Misalnya dalam penjualan consumer goods, yaitu produk sehari-hari rumah tangga dan individu, dipergunakan pendekatan yang berdasarkan ilmu perilaku konsumen. Tiap masyarakat konsumen dibagi-bagi atau dipilah melalui metode segmentasi pasar sesuai dengan kebutuan dan respon mereka pada usaha pemasaran (Kottler, dII). Dengan demikian, kelompok konsumen yang paling menghasilkan sales terbesar menimbulkan hadirnya penjual yang bersaing sangat ketat. Demi meningkatkan daya saing, maka produsen mengefektifkan dan efisiensikan segala proses produksi dan oprasi mulai dari hulu sampai hilir. Hal ini terjadi baik itu dalam setiap transaksi perdagangan ekonomi yang bersifaf regional maupun yang bersifat global. Di dalam proses ekonomi tersebut, peran konsumen adalah pasif yaitu sebagai pembelanja dan pengguna serta pengevaluasi mutu produk atau layanan yang diterimanya.

Nyatanya, orang banyak sebagai konsumen, seperti ibu-ibu rumah tangga mempunyai peranan yang sangat penting dan strategis dalam siklus transaksi perekonomian di dalam suatu negara. Perilaku konsumen dapat mempengaruhi hukum permintaan dan hukum penawaran serta fluktuasi harga. Dampaknya terasa secara makro dan mikro. Dari penjelasan di atas muncul suatu kesimpulan bahwa meskipun sesungguhnya konsumen itu memiliki peranan yang sangat strategis dalam rantai transaksi ekonomi, namun peranan konsumen nyatanya selalu menjadi pihak yang dikendalikan oleh berbagai macam strategi dan kebijakan-kebijakan

${ }^{10}$ Geert Hofstede, "Dimensionalizing Cultures: The Hofstede Model in Context," Online Readings in Psychology and Culture 2, no. 1 (December 1, 2011), doi:10.9707/2307-0919.1014. 
yang dikeluarkan oleh berbagai macam sistem ekonomi di atas dalam rangka untuk merebut pangsa pasar dengan persaingan yang sangat ketat. Dengan tujuan tidak lain untuk mempertahankan posisi konsumen, sebagai penerima sehingga posisi konsumen selalu rentan. Kalaupun terdapat suatu sistem perlindungan pada mereka, hal ini hanya berupa undangundang, dan hadirnya badan seperti BPOM atau Food and Drug Administration. Tidak banyak sistem yang memberdayakan atau mengubah posisi konsumen dari penerima menjadi penentu aktif dan berinteraksi satu sama lain. Mereka tetap menjadi pembelanja atau pihak yang mengeluarkan dana dan dalam prosesnya tidak menjadi investasi, kecuali di dalam kasus asuransi Jiwa.

Untuk menawarkan pilihan pada praktek yang sudah lama di atas, maka suatu konsep yang merupakan pilihan lain diketengahkan sebagai berikut dengan suatu landasan pemikiran bahwa, konsumen adalah pasar dan sekaligus modal sosial yang tidak pernah terpikirkan selama ini. Interaksi dan transaksi sosial, moral, komunitas adalah modal sosial yang tak terbatas, karena transaksi atau tepatnya relasi tersebut sangat dekat dengan hati nurani manusia. Konsep Ekonomi Gotong Royong, menekankan solidaritas dan keadilan, ketika kesejahteraan pribadi yang diperoleh melalui kegiatan perekonomian dinikmati bersama komunitas secara relasional kekeluargaan. Jadi, modal utama dalam sistem ekonomi gotong royong ini adalah relasi, komunitas, moral dan kekeluargaan, Jadi salah fitur sistem ini adalah keseimbangan mengutamakan nilai-nilai materi dan non-material alias relasional serta komunal atau koinonia ${ }^{11}$ dan perichoresis alias "berdansa bersama."12 Tentu yang dimaksud di sini adalah baik produsen maupun konsumen berdansa bersama dalam suatu tarian indah yang saling memperlengkapi dan memberdayakan, bukan memperdayakan.

\section{Modal utama: Nilai-nilai luhur}

Nilai adalah apa yang dianggap sebagai hal yang bernilai yang harus ada di dalam hidup dan diupayakan. Dalam kaitan dengan Ekonomi Gotong royong, nilai moral dimaksudkan sebagai suatu nilai yang terkait dengan kesadaran berkeluarga dan Komunitas (sense of community and family). Nilai ini sarat dengan potensial untuk dikembangkan karena mengandung konsistensi dan hal-hal luhur. Seperti dijelaskan dalam konsep nilai dari Rokeach, nilai-nilai itu antara lain adalah kepedulian, suka berbagi, empati, suka menolong, suka melindungi, guyub, tidak tega, rendah hati, spontan, tulus, ramah, toleran, kooperatif dll, dan semua itu adalah kekuatan moral dan nilai-nilai yang luar biasa yang turun temurun diwariskan sejak dulu. ${ }^{13}$ Inti dari nilai-nilai warisan masyarakat Indonesia tersebut adalah kesadaran relasional dan komunal. Artinya sangat penting dalam perilaku sehari-hari setiap orang menyadari bahwa ia adalah manusia yang sepanjang hidupnya adalah berelasi atau hidup dalam relasi. Manusia Indonesia sejak dulu juga menjadikan panduannya bahwa, ia hidup di dalam Komunitas sehingga harus memelihara dan mengembangkan komunitasnya. Masyarakat modern hanya perlu menyediakan wadah"-nya saja dan momen-momen yang tepat untuk menampung kekuatan moral tersebut. Sistem ekonomi gotong-royong dapat menjadi wadah itu.

11 Takesure Mahohoma, "Difficult Texts: Koinonia, Acts 2.42," Theology, 2017, doi:10.1177/0040571X17710202.

12 "(3) (PDF) Koinomics: An Indonesian Framework of Transformative Theological Education Based on Perichoresis (OCRPL Conference)," accessed April 16, 2021,

https://www.researchgate.net/publication/347488150_Koinomics_An_Indonesian_Framework_of_Transformative_Th eological_Education_based_on_Perichoresis_OCRPL_Conference.

${ }^{13}$ Richard L. Gorsuch, "Rokeach's Approach to Value Systems and Social Compassion," Review of Religious Research 11, no. 2 (1970): 139, doi:10.2307/3510277. 


\section{Modal Kedua: Mindset}

Dalam sistem ekonomi gotong royong ini setiap pemeran belajar memiliki mindset atau pola pandang bahwa setiap transaksi perdagangan dilaksanakan bersifat ekonomi mikro. Konsumen dilatih memandang diri sebagai pemilik komunitasnya. Mereka dilatih memelihara dan mengembangkan Komunitas dimana dirinya berada selain diri.

Sukses didefinisikan bukan timbulnya pribadi-pribadi yang memiliki harta yang banyak, namun bila kesenjangan mengecil dan setiap keluarga dalam anggota Komunitas tersebut cukup sejahtera (atau dalam ungkapan Jawa: "jogo tonggo" - alias saling mempedulikan sesama mulai dari tetangga terdekat). Dengan mindset tersebut misalnya, hutang tanpa bunga (transaksi finansial) akan dipandang sebagai investasi moral jangka panjang dan investasi bagi relasi yang berdampak pada kesejahteraan komunitas.

Sementara itu seorang investor akan dianggap sebagai seorang pelopor bagi peningkatan relasi dan kesejahteraan Komunitas. Ia adalah seseorang yang berjiwa dermawan (sosial capital) yang bersedia melakukan pembagian laba (profit sharing) dengan warga Komunitas yang menjadi konsumennya.

Jadi pada prinsipnya sistem ekonomi gotong royong ini adalah suatu komunitas masyarakat yang sepakat dan sehati untuk membangun kesejahteraan hidup bersama-sama dengan memupuk semangat solidaritas dan tanggung jawab bersama untuk saling melayani, saling berkomunikasi, saling berelasi dalam membangun keadilan sosial dengan azas kekeluargaan; ketika setiap anggotanya harus berpartisipasi di dalam proses produksi dan proses dalam setiap transaksi perdagangan, dan konsumen bisa menjadi pembeli juga bisa menjadi pemasok. ${ }^{14}$

Namun, mindset tersebut harus diterjemahkan ke dalam skill atau keterampilan mengelola dana, proses produksi atau layanan, pengelolaan SDM, dan marketing. Selain itu, di zaman modern kemampuan penggunaan teknologi digital dan membuat Jaringan hubungan menjadi suatu skillset yang perlu dimiliki.

\section{Modal Ketiga: Pendidikan}

Tentunya, sistem ini akan berjalan bila sebagian terbesar anggota Komunitas menyadari hal ini, memahami peran investasi moral dan makna relasi, dan kesadaran mengenai kekuatan di dalam jumlah populasi komunitasnya, serta pemahaman bahwa, keberhasilan yang sejati tidak merupakan hal yang bersifat individual saja, namun secara komunal. Dengan demikian modal ketiga yang dibutuhkan adalah Pendidikan bagi setiap Anggota Komunitas agar mengadopsi mindset yang sama.

Hal seperti ini sudah dilakukan di masa lalu oleh Count Zinzendorf dengan para petani di Moravia, atau kelompok Bruderhoff di Eropa dan USA, atau kalangan Anabaptis. Demikian pula prinsip ekonomi Syariah merupakan salah satu upaya untuk mewujudkan hal tersebut secara sistemik.

Di masa kini dengan adanya era digital, dimana interaksi, ekspresi, kolaborasi, ketersediaan infomasi yang melimpah, serta konvergensi dan jejaring menjadi warna dasar, pendidikan untuk meningkatkan kesadaran Ekonomi Gotong Royong di atas boleh jadi akan lebih serasi dengan Budaya era digital ini.

${ }^{14}$ Catatan: Meski secara esensi konsep ekonomi kekeluargaan ini bertolak dari pemikiran para founding fathers khususnya Pasal 33 UUD 1945, namun konsep prosumer (konsumen yang sekaligus menjadi produsen) juga disinggung oleh Alvin Toffler dalam karyanya: The Future Shock. 


\section{Modal Keempat: Spiritualitas dan Pandangan Teologis}

Spiritualitas pada dasarnya adalah kedekatan seseorang dengan Yang Disembahnya, yang membuat dirinya dapat memandang hidup secara berbeda atau memaknai, sehingga mendefinisikan suksesnya dan hubungan dengan orang lain secara berbeda. Spiritualitas akan menimbulkan perubahan nilai-nilai rujukan hidup dan keterlibatan dalam hidup orang lain. ${ }^{15}$

Secara spiritual, maka dalam Sistem Ekonomi Gotong Royong para anggota masyarakat perlu mendalami makna hidup yang berhasil dan makna kerja. Selain itu, mengimani relasi satu sama lain sebagai pemberian Yang Maha Kuasa dan perlu dipahami sebagai modal yang berharga.

\section{Analisis atas Komponen-komponen dalam Sistem Ekonomi Gotong Royong}

\section{Para Pemeran}

Pelopor/Investor/Perintis. Sistem ini berjalan bila ada sorang atau beberapa pemilik modal usaha yang mengalokasikan dananya untuk transaksi keuangan dan transaksi perdagangan yang bersedia membagi keuntungannya pada konsumen sebagai mitra usaha. Biasanya mereka dikenal dengan nama Angel Investor (pemodal yang berjiwa malaikat).

Mitra Usaha. Mitra usaha adalah konsumen yang terlibat langsung dalam proses transaksi simpan pinjam dan transaksi perdaganganyang mengikat perjanjian kerja sama untuk mengubah poin belanja menjadi vocher dan ikut memiliki usaha tersebut.

Mitra Kerja. Mitra kerja adalah seorang pekerja atau SDM yang menjalankan operasional dari sistem ekonomi gotong royong dan bisa juga memiliki vocher usaha tersebut serta bertanggungjawab pada pelopor/investor.

Mitra Jejaring. Mitra Jejaring adalah badan usaha, pabrik, pemasok. Marketer, distributor dan sebagainya yang mengadakan MOU dalam Operasional sistem ekonomi gotong royong mulai hulu sampai hilir.

\section{Proses Transaksi}

1. Sistem Hutang Atau Simpan Pinjam. Adalah Transaksi keuangan yang bersifat jangka panjang dan bertujuan untuk mengondisikan dan mengkoordinir seseorang/konsumen melalui usaha simpan pinjam yang dilakukan tanpa bunga dan angsuran yang disesuaikan kemampuan masing-masing orang dan juga sarana untuk menambah anggota baru.

2. Segmentasi Pasar. Segmentasi adalah proses mengelompokkan konsumen berdasarkan segala jenis kebutuhan mereka dan respon mereka pada upaya menjangkau mereka.

3. Poin Belanja. Poin Belanja adalah pembagian keuntungan yang dilakukan oleh pelopor/investor kepada mitra usaha dan mitra kerja, yang besarnya tergantung dari frekuensi pembelanjaan yang dilakukan oleh mereka. Sebagian keuntungan dalam transaksi perdagangan yang dibagi oleh pelopor/investor kepada mitra usaha dan mitra kerja, dan jumlah besarannya berdasarkan kesepakatan yang sudah disetujui bersama yang dihitung berdasarkan poin belanja yang di peroleh dari setiap transaksi.

4. Voucher. Adalah poin belanja yang di terima dari setiap transaksi yang dilakukan dan ditukar untuk transaksi belanja berikutnya yang dikelompokkan menurut voucher kebutuhan konsumen. Voucher Belanja dikelompokkan menjadi empat tipe: Tipe 1 adalah voucher belanja kuning yang dapat langsung dibelanjakan lagi. Tipe 2 adalah voucher belanja hijau yang dapat ditukarkan door prize yang di undi setiap satu bulan sekali dan juga mendapat

${ }^{15}$ Curtis Lehmann, "Understanding the Intersection of Spirituality and Service Engagement among Undergraduates from a Reasoned Action Approach," Journal of Higher Education Outreach and Engagement, 2019. 
kesempatan undian door prize di akhir tahun. Tipe 3 adalah voucher belanja biru yang dapat ditukarkan dengan profit sharing, dan di dalam setiap bulannya nilai voucher belanja itu bertambah nilai nomimalnya. Jika seandainya di bulan pertama nilai voucher itu Rp. 5000,maka kita akan mendapatkan profit sharing di akhir tutup buku sebesar Rp. 5000,- x 12 bulan = Rp. 60.000, - Maka, jika kita punya voucher di bulan kedua dengan nilai Rp. 10.000 maka kita akan dapat profit sharing di akhir tutup buku sebesar Rp. 10.000 × $11=$ Rp. 110.000,-.

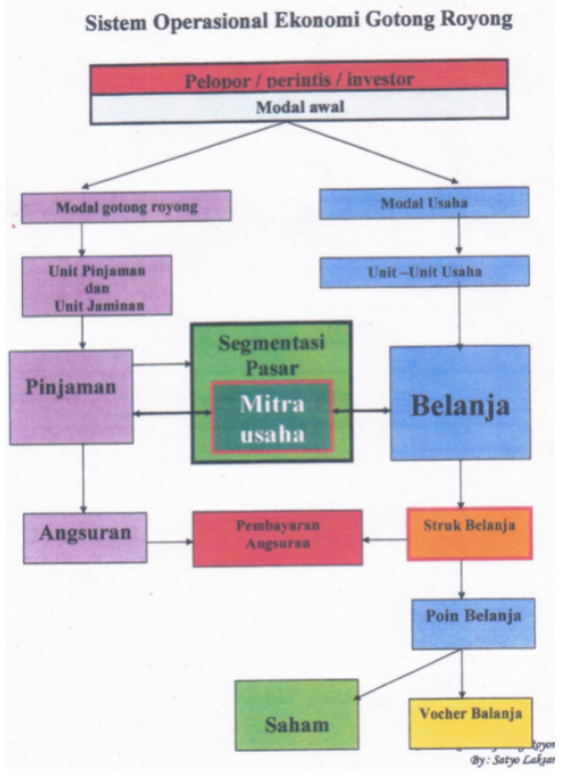

\section{Diagram 1. Skema Dasar Sistem Ekonomi Gotong Royong}

Jika kita punya voucher di bulan kesebelas dengan nilai Rp. 20.000 maka kita akan mendapatkan profit sharing di akhir tutup buku sebesar Rp. $20.000 \times 2=$ Rp 40.000,-. Jadi total profit-sharing yang kita terima di akhir tahun tutup buku adalah: Rp. $60.000+$ Rp. $110.000+$ Rp. $40.000=$ Rp. 210.000,-. Demikianlah ilustrasi sederhana akan yang dimaksudkan dengan investasi jangka pendek hanya dengan melakukan transaksi perdagangan saja. Angel Investor itu mestilah orang yang memiliki jiwa kemanusiaan yang luhur yaitu orang-orang yang sudah selesai dengan dirinya sendiri.

Tipe 4 adalah voucher belanja merah yang dapat dipergunakan untuk melakukan pinjaman uang tanpa bunga dengan besarnya angsuran yang dapat di negosasikan secara bersahabat. Point belanja dan voucher akan terus bertambah nilainya sampai 5 kali tahapan di setiap melakukan transaksi perdagangan dalam rentang waktu 1 bulan misalnya sewaktu kita melakukan transaksi pertama tgl 1 /..1/.. kita akan mendapatkan point belanja Rp 1000,-. Maka saat kita belanja lagi di bulan ../1 /.. yang sama dengan tgl 8/1/.. yang berbeda maka point/voucher kita akan bertambah nilainya menjadi Rp 2000,- dan akan terus bertambah sampai 5 kali saat kita melakukan transaksi perdagangan, yaitu sampai nilainya Rp 5000,-. Aturan ini juga berlaku untuk transaksi bulan berikutnya.

\section{Dua Contoh Penerapan Nyata di Lapangan}

Dari pemaparan ringkas di atas, tentunya akan muncul beberapa pertanyaan, misalnya: bagaimana caranya menerapkan gagasan sistem Ekonomi Gotong Royong tersebut? Berikut ini akan dipaparkan secara ringkas dua contoh penerapan konsep ekonomi gotong royong tersebut, walau dalam lingkup yang sangat mikro, 


\section{Penggalangan dana melalui bazaar gotong royong}

Pada tahun 2017 ketika bertugas sebagai panitia penyelenggara persekutuan udara terbuka di lingkungan gereja lokal, didapatkan oleh salah seorang dari penulis (SL) bahwa panitia menghadapi kebutuhan dana yang besar untuk menyelenggarakan suatu acara pertemuan terbuka yang akan melibatkan seluruh Jemaat ikut ambil bagian di dalamnya.

Setelah menghitung sesuai dengan rencana anggaran belanja yang sudah ditetapkan oleh Majelis Jemaat untuk kebutuhan yang diperlukan dalam acara tersebut, maka panitia menemukan kekurangan dana yang cukup besar yang harus dapat dicarikan solusi bersama-sama, baik itu dengan Majelis dan panitia serta juga dengan jemaat, karena acara tersebut akan dilaksanakan di suatu daerah wisata yang tiket masuknya cukup mahal bagi peserta.

Dengan adanya masalah tersebut di atas maka penulis mencoba menawarkan kepada panitia untuk mencari dana dengan metode sistem ekonomi gotong royong yang dikemas dengan model "bazar gotong royong."

Gagasan bazar gotong royong itu pelaksanaannya demikian: Jemaat dikondisikan bersama bahwa mereka adalah peserta yang akan ikut dalam acara PUT (persekutuan udara terbuka) tersebut dan kekurangan dana tersebut akan dicarikan dana melalui bazar gotong royong, yaitu kesempatan menjual berbagai hal. Dalam bazaar pihak yang akan berjualan nanti adalah jemaat dan yang membeli juga dari jemaat. Jemaat yang berjualan tetap mendapatkan keuntungan dari hasil barang yang dijualnya. Namun, panitia juga mengambil sebagian keuntungan dari proses jual beli tersebut. Jemaat diyakinkan oleh panitia bahwa berapapun harga jual barang-barang yang akan dibelinya itu hasil keuntungannya akan dipergunakan untuk membayar kekurangan harga tiket masuk ke tempat wisata itu. Jadi dari setiap transaksi jual beli, semua pihak diuntungkan bersama-sama: jemaat yang membeli diuntungkan karena tiket masuk wisata dapat terbayarkan dan jemaat yang menjual diuntungkan karena jualannya dapat terjual semua serta mendapat juga keuntungan sedikit dari hasil barang yang dijualnya. Panitia berperan dengan menciptakan pasar yang bersifat temporer untuk menggalang dana bagi acara PUT tersebut.

Contoh di atas adalah model sistem ekonomi gotong royong dalam skala ultramikro, namun yang penting hal ini kiranya menjadi ilustrasi yang baik dan utamanya prinsip-prinsip yang terkandung dalam sistem ekonomi gotong royong tersebut dapat terpenuhi, misalnya ada jemaat yang dikondisikan (sebagai konsumen), ada pasar yang dikondisikan (bazar gotong royong), dan juga ada pembeli dan penjual yang dikondisikan juga bahwa keuntungan dari hasil bazar tersebut akan dipergunakan bersama-sama untuk kepentingan jemaat, dan panitia hanya sebagai pelopor usahanya.

\section{Pelatihan eco-enzyme sebagai bentuk diakonia transformatif}

Seperti kita ketahui, ekonomi dunia cenderung melambat dalam setahun terakhir saat pandemi ini. Namun ada juga sektor sektor yang cenderung menguat, seperti sektor makanan, kesehatan dan kebersihan, dan juga:

- produk kesehatan untuk kesehatan tubuh,

- produk kesehatan untuk keperluan rumah tangga,

- produk kesehatan untuk makanan yang sehat,

- produk kesehatan dari hasil pertanian (khususnya: pertanian organik).

Peluang untuk produk-produk dari hasil pertanian organik khususnya, mengalami peningkatan yang cukup besar karena banyak konsumen mulai menyadari akan pentingnya makanan yang sehat untuk menjaga kesehatan. 
Dalam konteks tersebut, maka ada peluang yang sangat terbuka akan pengembangan pertanian organik, hidroponik dan lain-lain yang bertumpu pada eco-enzyme dan bio-enzyme. Eco-enzyme adalah protein esensial yang dibuat dari segala macam buah-buahan dan sayur yang difermentasi dalam jangka waktu tertentu agar dapat mengeluarkan enzyme yang terkandung dalam buah-buahan dan sayuran tersebut. Bio-enzyme dihasilkan dari mengembangkan mikro organisme secara fermentasi dan hal itu dapat menguntungkan bagi tanah, agar tanah dapat menghasilkan unsur hara yang diperlukan bagi tanaman.

Hasil dari produksi eco-enzyme dan bio-enzyme sangat bermanfaat bukan saja untuk pertanian saja, akan tetapi hasil dari eco-enzyme ini bermanfaat juga guna:

- meningkatkan kinerja mikro organisme di dalam tanah

- untuk terapi kesehatan

- untuk meningkatkan kualitas udara

- untuk menjernihkan air

- untuk vitamin pada ikan dan ternak

- untuk mengurangi bau spitenk dan bau got

- untuk mengurangi bau pada cucian baju

- bisa digunakan sebagai sabun mandi organik

- bisa untuk membersihkan sayur dan buah dari petisida

- bisa sebagian untuk pestisida alami.

Dengan komposisi buah-buahan dan sayur tertentu eco-enzyme dapat juga dipakai untuk terapi kecantikan dan kesehatan. Eco-enzyme ini dapat juga untuk membantu proses metabolisme di dalam tubuh yang biasa disebut dengan eco-classic enzyme yang dibuat dari daging buah segar yang difermentasi dengan madu.

Apa yang ditawarkan

1. Untuk tanaman organik: kerja sama dengan supermarket, "Lotte" misalnya.

2. Untuk produk sayur dalam kemasan, dipasarkan secara online.

3. Jasa perawatan tanaman.

4. Jasa semprot udara segar.

5. Pelatihan pertanian organic, pembuatan pupuk dari sampah sayur dan buah, dan lain sebagainya.

Apa yang dicapai adalah dengan meningkatkan kualitas kesehatan dan juga kualitas spiritual yaitu menyadari alam ciptaan sebagai pemberian Tuhan, maka mendekatkan diri kembali ke "alam" dan bersahabat dengan bumi ini adalah solusi yang paling tepat seusai Kehendak Allah. Usaha-usaha yang bersifat komunitas/komunallah yang akan dapat mendukung kesejahteraan yang bersifat personal, di sinilah hakekat gotong royong itu menjadi sangat penting dan sangat indah.

\section{Analisis pada Proses Manajemen}

Penerapan Sistem Ekonomi Gotong royong yang berlandaskan nilai-nilai relasional kekeluargaan atau komunal. Dalam proses manajemennya maka, orang banyak berperan sebagai subjek dari sistem ekonomi. Artinya, mereka turut serta dalam proses produksi, pemasaran, penataan SDM, dan pengelolaan keuangan, serta akan mendapat bagian laba atau surplus melalui keterlibatan mereka. Pembagian kerja dan penguasaan skill untuk setiap proses di atas akan menentukan keberhasilan sistem Ekonomi Gotong Royong sehingga setiap orang harus terus menerus belajar. 


\section{Penutup}

Keberhasilan suatu sistem seperti di atas tidak akan serta merta terjadi. Di Bali, sistem Subak berhasil karena, sistem ekonomi ini yaitu penyediaan air bagi pertanian digandeng dengan sistem sosial yaitu desa bersama sebagai komunitas yang kuat. Di kalangan Muslim, sistem ekonomi Syariah juga membutuhkan pendidikan berkelajutan bagi umat. Jadi mendasari seluruhnya adalah diperlukan suatu kesamaan mindset mengenai makna hidup, manusia yaitu diri sendiri dan orang lain, serta Yang Maha Kuasa sebagai pemberi kesempatan manusia hidup di dalam relasi yang saling mensejahterakan. Dengan demikian diperlukan suatu spiritualitas yang dipelihara dan terus diperdalam. Dapat disimpulkan bahwa, pendidikan pada setiap anggota komunitas masyarakat akan sangat menentukan Sistem Ekonomi Gotong Royong ini. Musuh atau penghambat perwujudan sistem ekonomi di atas terdapat pada egoism atau individualisme yang berkelebihan.

\section{REFERENSI}

Robby Chandra \& Victor Christianto. Koinomics: An Indonesian Framework of Transformative Theological Education Based on Perichoresis (OCRPL Conference)." Accessed April 16, 2021. https://www.researchgate.net/publication/347488150_Koinomics_An_Indonesian_Frame work_of_Transformative_Theological_Education_based_on_Perichoresis_OCRPL_Confer ence.

d'Albis, Hippolyte. "Demographic Structure and Capital Accumulation." Journal of Economic Theory 132, no. 1 (January 2007): 411-34. doi:10.1016/j.jet.2005.10.001.

Gorsuch, Richard L. "Rokeach's Approach to Value Systems and Social Compassion." Review of Religious Research 11, no. 2 (1970): 139. doi:10.2307/3510277.

Hofstede, Geert. "Dimensionalizing Cultures: The Hofstede Model in Context." Online Readings in Psychology and Culture 2, no. 1 (December 1, 2011). doi:10.9707/23070919.1014.

Khasanov, Ilyos Makhmudovich. "Essence, Mission And Value Of Enterpreneurship Activity." The American Journal of Management and Economics Innovations 03, no. 02 (February 28, 2021): 38-45. doi:10.37547/tajmei/volume03issue02-05.

Lehmann, Curtis. "Understanding the Intersection of Spirituality and Service Engagement among Undergraduates from a Reasoned Action Approach." Journal of Higher Education Outreach and Engagement, 2019.

Mahohoma, Takesure. "Difficult Texts: Koinonia, Acts 2.42." Theology, 2017. doi:10.1177/0040571X17710202.

Statistik, Badan Pusat. "Hasil Sensus Penduduk 2020." Januari, 2021. https://www.bps.go.id/pressrelease/2021/01/21/1854/hasil-sensus-penduduk-2020.html.

"The Power of Large Numbers: Population, Politics, and Gender in Nineteenth-Century France on JSTOR." Accessed April 16, 2021. https://www.jstor.org/stable/10.7591/j.ctv75d49n.

Thibodeau, Paul H., and Lera Boroditsky. "Metaphors We Think with: The Role of Metaphor in Reasoning." PLOS ONE 6, no. 2 (2011). doi:10.1371/journal.pone.0016782. 